\title{
Effects of Body Weight, Adrenal Status, and Estrogen Priming on Hypothalamic Progestin Receptors in Male and Female Rats ${ }^{1}$
}

\author{
ANNE M. ETGEN ${ }^{2}$ \\ Department of Biological Sciences, Rutgers University, New Brunswick, New Jersey 08903
}

\begin{abstract}
Some laboratories have reported sex differences in the effect of estrogen priming on neural progestin receptor concentration, whereas others find no such differences. The present studies sought to identify experimental variables which might differentially influence the measurable level of hypothalamic cytosol progestin receptors in adult male and female rats. The influence of three variables, body weight, adrenal status, and estrogen priming regimen, was evaluated. Treatment with low doses of estrogen (2 or $8 \mu \mathrm{g}$ of estradiol benzoate (EB) $48 \mathrm{hr}$ before sacrifice) was slightly but not significantly more effective in elevating hypothalamic progestin receptor content in age-matched females than in males despite the $40 \%$ greater body weights of males. When the same doses of EB were administered per $\mathbf{2 0 0} \mathbf{g m}$ of body weight to animals with and without adrenal glands, both basal and estrogen-induced levels of hypothalamic progestin receptor were significantly higher in adrenalectomized/gonadectomized rats than in rats which were gonadectomized only, regardless of sex. There was no significant effect of sex or any interaction between sex, adrenal status, or estrogen priming dose. The only significant sex difference in brain progestin receptors occurred when weight-matched males and females received multiple injections of higher priming doses of estrogen (three daily injections of $10 \mu \mathrm{g}$ of EB). Under these conditions, females showed up to 2-fold higher levels of hypothalamic progestin receptors than males, regardless of adrenal status. These data suggest that sex differences may exist in the neural progestin receptor systems of male and female rats, but the relationship of these differences to sex differences in neuroendocrine function or behavior is not clear.
\end{abstract}

Research on sex differences in the central nervous system has expanded rapidly in recent years. Although the list of recognized sexual dimorphisms in brain anatomy and chemistry has lengthened considerably, the relationship of such differences to sex differences in animal physiology generally remains unclear. Shortly after the unequivocal demonstration that rodent brain contains specific, sat-

Received October 22, 1984; Revised January 28, 1985;

Accepted February 21, 1985

${ }^{1}$ This work was supported by National Institute of Mental Health Grant MH 36041, Biomedical Research Support Group Grant PHS RR7058, and a grant from the Charles and Johanna Busch Memorial Fund. The excellent technical assistance of Alan Gerstein and Joan Sorenson is gratefully acknowledged.

${ }^{2}$ To whom correspondence and reprint requests should be sent, at her present address: Department of Psychiatry, Albert Einstein College of Medicine, 1300 Morris Park Ave., Bronx, NY 10461. urable, high affinity progestin-binding macromolecules (receptors; Kato and Onouchi, 1977; Moguilewsky and Raynaud, 1977), sex differences in neural progestin receptors were reported. Moguilewsky and Raynaud (1979) found that estrogen priming, which activates estrous behavior in female but not in male rats, was less effective in elevating hypothalamic-preoptic area (HPOA) progestin receptor levels in males than in females. Neither these authors nor Thrower and Lim (1980) observed sex differences in brain progestin receptor levels between gonadally intact males and ovariectomized females which had not been treated with estrogen. More recently, Rainbow et al. (1982) reported that castrated, estrogen-primed male rats have fewer cytosol progestin receptors in the ventromedial nucleus (VMN) of the hypothalamus and periventricular region of the preoptic area than do similarly treated females. These data have led the authors to suggest that the differential expression of estrous behaviors in male and female rats might result from a deficiency in estrogen induction of HPOA progestin receptors in males.

Another laboratory, however, has reported that estrogen greatly incrcascs cytosol progestin receptor levels in hypothalamus of castrated male rats (Naess and Attramadal, 1978). Still other laboratories have found that estrogen priming produces comparable increases in HPOA progestin receptor levels in normal females, normal males, and neonatally androgenized or estrogenized females (Etgen, 1981; Ghraf et al., 1983; Kirchoff ct al., 1983). Of these four groups of rats, only normal females show high levels of estrous behavior in response to estrogen plus progestin treatment in adulthood. These data question the relationship between estrogen induction of HPOA progestin receptors and the differential sensitivity of male and female rats to the estrous behavior-facilitating properties of estrogen.

In view of the large discrepancies in estrogen inducibility of brain progestin receptors in male and female rats reported by independent laboratories and the consequent interpretation of such data in terms of sex differences in brain responsiveness to estrogen stimulation, it seemed important to reinvestigate the induction of HPOA progestin receptors by estrogen in the two sexes. More specifically, the present experiments sought to identify factors other than sex which might influence the measurement of brain cytosol progestin receptor content in male and female rats.

\section{Materials and Methods}

General methods. Sprague-Dawley rats obtained from Blue Spruce Farms, Inc. (Altamont, NY) or Harlan Sprague-Dawley (Indianapolis, IN) were used throughout. Animals were housed by sex in groups of two to four and were maintained on a 12-hr/12-hr reversed light/dark cycle (lights off at 9:30 AM) with food and water available ad libitum. Bilateral gonadectomy and/or adrenalectomy was performed under Metofane anesthesia (Pitman-Moore, inc., Washington Crossing, NJ). Adrenalectomized animals were given $1.0 \%$ $\mathrm{NaCl}$ in their drinking water up until the time of sacrifice. All hormone injections were given subcutaneously in peanut oil vehicle.

Materials. The steroid $17-\beta$-estradiol benzoate (EB) was purchased from Steraloids, Inc. (Wilton, $\mathrm{NH}$ ) and dissolved in peanut oil prior to injection. The radiolabeled progestin $\mathrm{R} 5020\left(17 \alpha-\left[\right.\right.$ methyl $\left.^{3} \mathrm{H}\right] \mathrm{R} 5020$; specific activity, 87 
$\mathrm{Ci} / \mathrm{mmol}$ ) and unlabeled R5020 were obtained from New England Nuclear Corp. (Boston, MA) and checked for purity by thin layer chromatography before use and at regular intervals throughout the experiment. All other chemicals were of reagent grade.

Progestin receptor assays. Animais were sacrificed by decapitation, and the entire HPOA was removed as described previously (Etgen, 1979). Cytosol progestin receptor levels were assayed in freshly dissected tissue using a modification of the method of Ginsburg et al. (1974). Pooled tissue from two or three animals was homogenized in ice-cold buffer $(10 \mathrm{mM}$ Tris- $\mathrm{HCl}, \mathrm{pH}$ 7.4 at $0^{\circ} \mathrm{C} ; 1.5 \mathrm{mM} \mathrm{Na}_{2} \mathrm{EDTA} ; 12 \mathrm{~mm}$ monothioglycerol; $10 \%(\mathrm{v} / \mathrm{V})$ glycerol; TEMG) in Teflon-glass tissue grinders. The homogenate was centrifuged at $850 \times g$ for $10 \mathrm{~min}$, and the resulting supernatant was recentrifuged at $105,000 \times g$ for $1 \mathrm{hr}$. The clear high speed supernatant (cytosol) was removed and used immediately. Aliquots (150 or $200 \mu \mathrm{l})$ of cytosol were incubated at $0^{\circ} \mathrm{C}$ for $5 \mathrm{hr}$ with radiolabeled $\mathrm{R} 5020$ in the presence or absence of 1,000-fold excess unlabeled R5020. For one-point assays, the final subsaturating concentration of $\left[{ }^{3} \mathrm{H}\right] \mathrm{R} 5020$ was $0.5 \mathrm{~nm}$. For saturation analyses, the $\left[{ }^{3} \mathrm{H}\right] \mathrm{R} 5020$ concentration in the incubations ranged from 0.1 to 3 nм. Bound $\left[{ }^{3} \mathrm{H}\right] \mathrm{R} 5020$ was separated from free $\left[{ }^{3} \mathrm{H}\right] \mathrm{R} 5020$ by applying samples of each incubate $(200 \mu l)$ to individual minicolumns $(0.5 \times 9 \mathrm{~cm})$ of Sephadex LH-20 equilibrated in TEMG. Samples were washed in with $200 \mu \mathrm{l}$ of TEMG, and bound radioactivity was eluted in the first $0.8 \mathrm{ml}$ following the void volume directly into scintillation minivials. Scintillation fluid $(5 \mathrm{ml}$ of Tritosol) was added, and radioactivity was counted in a Beckman LS-100C liquid scintillation counter with an automatic external standard. Specific binding was calculated by subtracting nonspecific binding (with excess unlabeled R5020) from total binding (without excess unlabeled R5020)

\section{Results}

Effects of body weight. Since adult male rats are considerably heavier than females of the same age, it is possible that agematched males and females would show different levels of estrogeninduced progestin receptors because males receive a lower effective hormone dose if body weight is not considered at the time of estrogen administration. Therefore, the first experiment measured estrogen induction of HPOA cytosol progestin receptors in agematched adult (65 to 100 days old) male and female rats which differed by approximately $40 \%$ in total body weight (range, 30 to $46 \%$ ). Animals which had been gonadectomized for at least 4 days received 2 or $8 \mu \mathrm{g}$ of EB or oil vehicle and were sacrificed $48 \mathrm{hr}$ later for determination of progestin receptor levels. In four independent replications, vehicle-injected males and females showed comparable levels of receptor (4 to $5 \mathrm{fmol} / \mathrm{mg}$ of protein). Figure 1 shows that females given $2 \mu \mathrm{g}$ of EB had $11 \%$ greater induction of HPOA

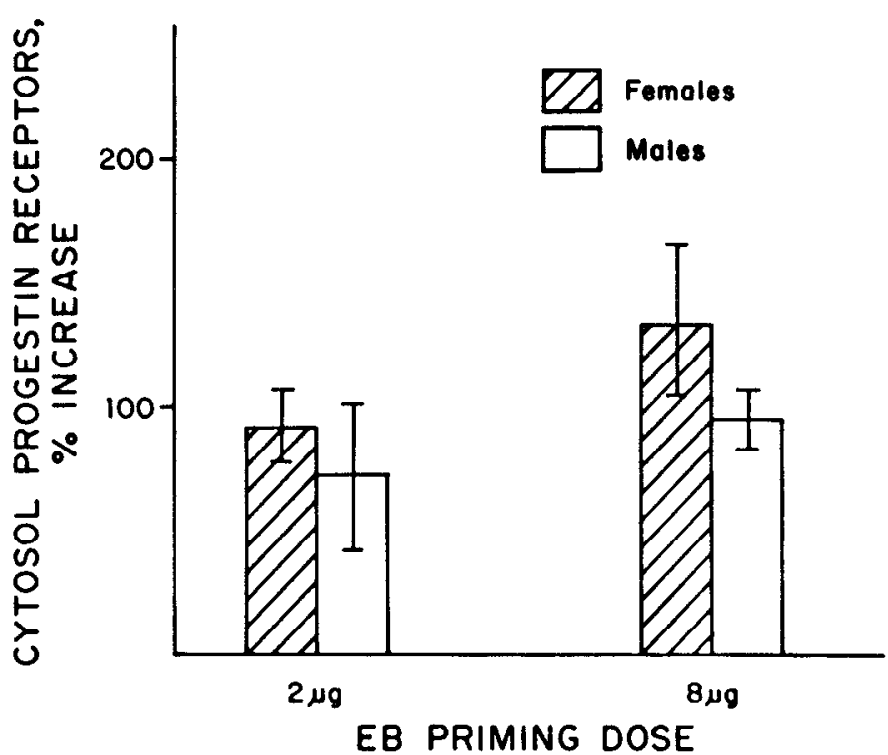

Figure 1. Induction of HPOA cytosol progestin receptors by 2 or $8 \mu \mathrm{g}$ of EB in age-matched male and female rats which differed by $40 \%$ in body weight. Data are expressed as percentage of increase compared to vehicleinjected controls, and each value represents the mean of four independent replications

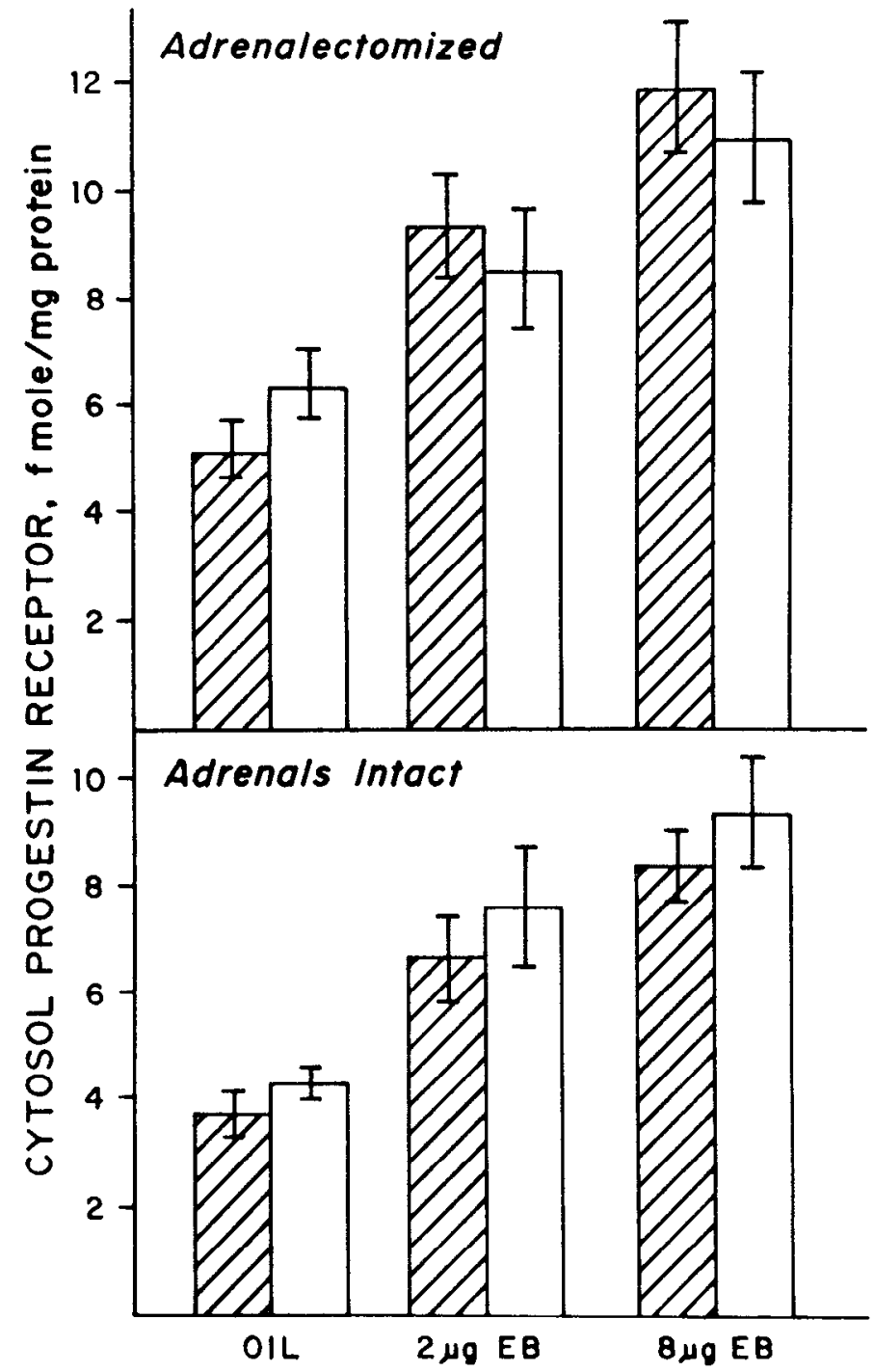

Figure 2. HPOA cytosol progestin receptor levels in gonadectomized (adrenals intact) and gonadectomized/adrenalectomized male and female rats given oil vehicle, 2 or $8 \mu \mathrm{g}$ of EB/200 gm of body weight. Hatched bars, females; open bars, males. Analysis of variance revealed significant differences as a function of adrenal status and estrogen priming dose (see the text for details). Each value represents the mean of five to seven independent replications.

cytosol progestin receptors than did age-matched males; at the 8$\mu \mathrm{g}$ dose, EB induced $21 \%$ more receptor in females than in males. Thus, females tended to show slightly greater elevations in brain progestin receptor levels in response to low doses of EB given as a single injection, but neither of these differences was statistically significant ( $t$ tests, $p>0.05$ ). Therefore, it is likely that body weight differences in age-matched males and fermales do not account for the observation of sex differences in neural progestin receptors by some laboratories (Moguilewsky and Raynaud, 1979; Rainbow et al., 1982). However, since there was a small but consistent difference between the sexes, EB was administered relative to body weight in the remainder of the experiments.

Effect of adrenal status. It has been suggested that the increased release of adrenal steroids following castration in male rats might interfere with measurement of progestin receptor levels in males due either to competition by endogenous steroids for cytosol-binding sites or to translocation of cytosol receptors to the nuclear compartment (Etgen, 1981, 1984). Scatchard analysis of HPOA cytosol progestin receptors in castrated and castrated/adrenalectomized males suggested that, although the affinity of $\left[{ }^{3} \mathrm{H}\right] \mathrm{R} 5020$ for binding 

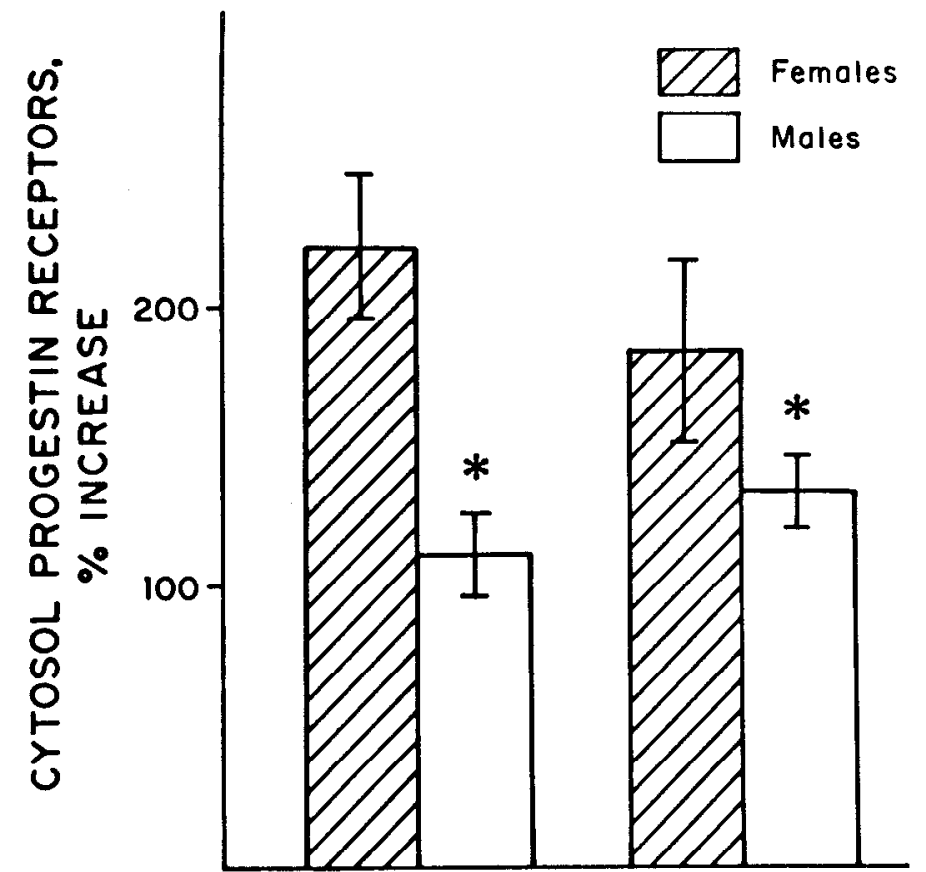

Adrenals Intact Adrenalectomized

Figure 3. Induction of HPOA cytosol progestin receptors by three daily injections of $10 \mu \mathrm{g}$ of EB in weight-matched male and female rats. Data are expressed as percentage of increase compared to vehicle-injected controls, and each value represents the mean of four to five independent replications. ${ }^{\star}, p<0.025, t$ tests.

sites did not differ between the two groups, the maximum number of binding sites was always greater in rats that had been both castrated and adrenalectomized (data not shown). Thus, the following experiments evaluated both basal progestin receptor levels and estrogen induction of I IPOA progestin receptors in gonadectomized and gonadectomized/adrenalectomized males and females. The weights of animals ranged from 180 to $220 \mathrm{gm}$, and EB injections were administered as 2 or $8 \mu \mathrm{g} / 200 \mathrm{gm}$ of body weight $48 \mathrm{hr}$ before sacrifice. Adrenalectomies were performed $72 \mathrm{hr}$ before sacrifice.

Figure 2 shows the level of HPOA cytosol progestin receptors, in femtomoles per milligram of protein, measured in gonadectomized and gonadectomized/adrenalectomized male and female rats primed with oil vehicle or 2 or $8 \mu \mathrm{g}$ of EB. The data were subjected to a three-way analysis of variance (sex $x$ adrenal status $\times$ EB dose) using an SAS GLM procedure and least squares means for planned post hoc comparisons (SAS User's Guide, 1979). Significant differences were found as a function of adrenal status $(F=9.59$; $d f=$ $1,58 ; p<0.003)$ and $\mathrm{EB}$ dose $(F=26.58 ; d f=2,58 ; p<0.0001)$. There were no significant sex differences or any significant interactions between sex, adrenal status, and EB dose. Thus, adrenalectomized rats had higher measurable brain cytosol progestin receptor levels regardless of sex or estrogen priming. As suggested by the preliminary Scatchard analyses, vehicle-injected control males had 45 to $60 \%$ more available progestin-binding sites when they were both castrated and adrenalectomized than when they were only castrated. Ovariectomized females also had higher basal levels of neural progestin receptors when they were adrenalectomized, but the difference was somewhat less than in males (30 to $40 \%$ ). In addition to the adrenal effects, post hoc pairwise comparisons indicated that $8 \mu \mathrm{g}$ of EB induced significantly higher levels of progestin receptors than did $2 \mu \mathrm{g}$, regardless of sex or adrenal status (least squares means, $p<0.02$ ) and that both 2 and $8 \mu \mathrm{g}$ of EB significantly elevated receptors in comparison with vehicle controls (least squares means, $p<0.0001$ ).

Effects of estrogen priming regimen. Results of the first two experiments indicate that the observation of sex differences in HPOA progestin receptor induction by some investigators but not others cannot be attributed entirely to procedural differences such as failure to control for body weight or adrenal status. The most robust sex difference in estrogen induction of brain progestin receptors was reported by Rainbow et al. (1982). Those investigators used EB priming procedures ( $10 \mu \mathrm{g} /$ day for 3 days before sacrifice) different from the ones used in the present study. Therefore, a final experiment evaluated the effects of the EB priming procedure on progestin receptor induction in gonadectomized and gonadectomized/adrenalectomized male and female rats. Animals were adrenalectomized 4 days before sacrifice, and estrogen priming was the same as that reported by Rainbow et al. (1982), i.e., $10 \mu \mathrm{g} /$ day for 3 days before sacrifice. Control rats received parallel injections of oil vehicle, and all animals were sacrificed $24 \mathrm{hr}$ after the last injection.

As shown in Figure 3, significant sex differences in estrogen induction of HPOA cytosol progestin receptors can be observed when animals receive more prolonged priming with higher EB doses. In gonadectomized animals with intact adrenals, the magnitude of progestin receptor induction was twice as high in females as in males $(t=6.88, d f=7, p<0.005$ ). Although the sex difference was not as great in adrenalectomized animals (females $=181 \%$ increase; males $=133 \%$ increase), it was still statistically significant $(t=2.52, d f=8, p<0.025)$. Control levels of HPOA progestin receptor were comparable to those shown in Figure 2.

\section{Discussion}

These results indicate that al least two variables olther than sex, namely, adrenal status and estrogen priming dose, may influence the measurement of brain cytosol progestin receptors in adult rats. A third variable, body weight, appeared to play a minor or negligible role. Despite the $40 \%$ greater body weights of male rats when compared to age-matched female counterparts, there was no significant sex difference in the level of progestin receptor induced in the HPOA by 2 or $8 \mu \mathrm{g}$ of EB.

Adrenal effects on neural progestin receptors are more complicated. The second experiment demonstrated that when body weight was controlled, adrenalectomy significantly increased both basal and estrogen-induced levels of HPOA progestin receptors in both sexes. This result is consistent with earlier observations of increased brain uptake of progesterone in adrenalectomized rats (Whaien and Luttge, 1971). However, in the third experiment, which used much higher priming doses of $\mathrm{EB}$, the induced level of progestin receptor was consistently lower in adrenalectomized animals. Thus, it appears that the adrenal gland can modify profoundly the measurement of brain progestin receptors, but the underlying mechanism is not obvious. We cannot mimic the effect of adrenalectomy by treating animals with metyrapone, an inhibitor of adrenal steroid biosynthesis, or by suppressing ACTH with high doses of dexamethasone (A. M. Etgen, unpublished observations). However, we have been unable to measure blood levels of steroids following drug treatments; thus, we cannot be certain that the metyrapone or dexamethasone effectively reduced adrenal steroid production and release. Therefore, it is not known whether the elevated progestin receptor levels in adrenalectomized rats reflect the loss of endogenous adrenal steroids which could compete for available cytosol-binding sites and/ or translocate receptor into the nucleus, or whether the adrenal regulates neural progestin receptors by a mechanism independent of (or in addition to) its steroid output. Although many questions remain to be answered regarding the role of the adrenal in modulating HPOA progestin receptors, the present data do lead to the conclusion that the use of adrenalectomized rats by some investigators (Ftgen, 1981; Ghraf et al., 1983; Kirchoff et al., 1983) does not account for their failure to detect sex differences in estrogeninduced progestin receptors.

The only condition which produced reliable, robust sex differences in HPOA cytosol progestin receptors in the present study was prolonged administration of higher doses of estrogen (10 $\mu \mathrm{g}$ of $\mathrm{EB}$ / day for 3 days).. With this estrogen priming regimen, female rats had 
consistently higher concentrations of HPOA progestin receptors than did their male counterparts. Comparable differences were never seen with lower doses of estrogen administered as a single injection, even when body weight and adrenal status were manipulated. Thus, it appears that the most important determinant of sex differences in estrogen induction of HPOA progestin receptors is the estrogen priming regimen. Single injections of relatively low doses of estrogen ( 2 and $8 \mu \mathrm{g}$ of EB), which are sufficient to facilitate estrous behavior in females but not males (Whalen et al., 1971; Whalen, 1974), do not produce significant sex differences in HPOA cytosol progestin receptors when administered to age- or weight-matched animals (see Figs. 1 and 2). It is not clear whether the observation of a significant sex difference in the final experiment resulted from the higher total dose of estrogen ( $30 \mu \mathrm{g}$ of EB) or from the timing of the injections (three daily injections of $10 \mu \mathrm{g}$ each). The data of Moguilewsky and Raynaud (1979) do not clarify this question. Although they administered single injections of 1 to $100 \mu \mathrm{g}$ of EB to males and females $40 \mathrm{hr}$ before sacrifice, they did not provide statistical comparisons between the sexes at any dose level. It should also be noted that the latter authors used a procedure to assay cytosol progestin receptors (dextran-coated charcoal method) that was radically different from either the present report or that of Rainbow et al. (1982), making it more difficult to compare the results of these three studies.

An important procedural difference between the present cxperi ments and those of Rainbow et al. (1982) is neuroanatomical specificity. The latter study quantified cytosol progestin receptor levels in individual, microdissected nuclei of the rat brain rather than in grossly dissected tissue blocks as used in the present study. Therefore, the results of the two studies are not directly comparable. For example, it is conceivable that sex differences would have been noted in our first two experiments specifically in the VMN and periventricular preoptic area had we assayed microdissected tissue. Perhaps the trend toward lower levels of estrogen-inducible receptors in age-matched males (see Fig. 1) would have been attributable entirely to differences in these two nuclei. However, it is also possible that microassay of cytosol progestin receptor content in hypothalamic and preoptic nuclei trom rats given much lower doses of estrogen would fail to reveal significant sex differences when both body weight and adrenal status were controlled. The only other report of estrogen induction of cytosol progestin receptors in microdissected brain nuclei (Parsons et al., 1982) used even higher priming doses of EB ( $20 \mu \mathrm{g} /$ day for 3 days). Thus, it is difficult to evaluate whether the comparatively reduced level of progestin receptors found in the VMN of estrogen-primed males is less than, equal to, or greater than the concentration which would be induced in females by low but behaviorally active estrogen doses.

Results of this study suggest that the physiological significance of reported sex differences in the brain progestin receptor system must be interpreted cautiously. Although it is clear that the neural progestin receptor systems of male and female rats do not always respond in the same way to estrogen priming, it is not clear how these sex differences relate to any known sexual dimorphisms in neuroendocrinology or behavior. Since behaviorally effective doses of EB given as a single injection can produce comparable levels of induced progestin receptor in the HPOA of males and females, it may be premature to speculate that the insensitivity of male rats to the estrous behavior-promoting actions of ovarian steroids are causally related to the insensitivity of their neural progestin receptor system to stimulation by estrogen. In fact, it is possible that the differences observed in this study may be entirely unrelated to sexual dimorphisms in brain responsiveness to estrogen. Rather, they may reflect sex differences in liver metabolism of steroids (for a recent review see Gustafsson et al., 1983) or in progestin receptor translocation (Kato et al., 1984), nuclear retention, or processing.

\section{References}

Etgen, A. M. (1979) Antiestrogens: Effects of tamoxifen, nafoxidine and $\mathrm{Cl}$ 628 on sexual behavior, cytoplasmic receptors, and nuclear binding of estrogen. Horm. Behav. 13: 97-112.

Etgen, A. M. (1981) Estrogen induction of progestin receptors in the hypothalamus of male and female rats which differ in their ability to exhibit cyclic gonadotropin secretion and female sexual behavior. Biol. Reprod. 25: $307-313$.

Etgen, A. M. (1984) Progestin receptors and the activation of female reproductive behavior: A critical review. Horm. Behav. 18: 411-430.

Ghraf, R., J. Kirchoff, W. Grunke, W. Reinhardt, P. Ball, and R. Knuppen (1983) Estrogen responsiveness of progestin receptor induction in the pituitary, preoptic-hypothalamic brain and uterus of neonatally estrogenized female rats. Brain Res. 258: 133-138.

Ginsburg, M., B. D. Greenstein, N. J. MacLusky, I. D. Morris, and P. J. Thomas (1974) An improved method for the study of high-affinity steroid binding:oestradiol binding in brain and pituitary. Steroids 6: 773-792.

Gustatsson, J-A., A. Mode, G. Norstedt, and P. Skett (1983) Sex steroid induced changes in hepatic enzymes. Annu. Rev. Physiol. 45: 51-60.

Kato, J., and T. Onouchi (1977) Specific progesterone receptors in the hypothalamus and anterior hypophysis of the rat. Endocrinology 101:920928.

Kato, J., T. Onouchi, S. Okinaga, and M. Takamatsu (1984) The ontogeny of cytosol and nuclear progestin receptors, in male rat brain and its malefemale differences. J. Steroid Biochem. 20: 147-153.

Kirchoff, J., W. Grunke, and R. Ghraf (1983) Estrogen induction of progestin receptors in pituitary, hypothalamic and uterine cytosol of androgenized female rats. Brain Res. 275: 173-177.

Moguilewsky, M., and J-P. Raynaud (1977) Progestin binding sites in the rat hypothalamus, pituitary and uterus. Steroids 30: 99-109.

Moguilewsky, M., and J.P. Raynaud (1979) The relevance of hypothalamic and hypophyseal progestin receptor regulation in the induction and inhibition of sexual behavior in the female rat. Endocrinology 105: 516-522.

Naess, O., and A. Attramadal (1978) Progestin receptors in the anterior pituitary and hypothalamus of male rats. Int. J. Androl. Suppl. 2: 175-183.

Parsons, B., T. C. Rainbow, N. J. Maclusky, and B. S. McEwen (1982) Progestin receptor levels in rat hypothalamic and limbic nuclei. J. Neurosci. 2: $1446-1452$.

Rainbow, T. C., B. Parsons, and B. S. McEwen (1982) Sex differences in rat brain estrogen and progestin receptors. Nature 300: 648-649.

SAS Users Guide (1979) SAS Institute, Inc., Raleigh, NC.

Thrower, S., and L. Lim (1980) Characterization of rat hypothalamic progestin binding by spheroidal hydroxylapatite chromatography. Biochem. J. 186: 295-300.

Whalen, R. E. (1974) Estrogen-progesterone induction of mating in female rats. Horm. Behav. 5: 157-162

Whalen, R. E., and W. G. Luttge (1971) Role of the adrenal in the preferential accumulation of progestin by mesencephalic structures. Steroids 18: 141146.

Whalen, R. E., W. G. Luttge, and B. B. Gorzalka (1971) Neonatal androgenization and the development of estrogen responsivity in malc and female rats. Horm. Behav. 2: 83-90. 